\title{
Speciation of Antimony in Injectable Leishmanicidal Drugs by Lowering Citric Acid Concentration Used in Hydride Generation Atomic Absorption Spectrometry Analysis
}

\author{
Henrique J. F. Fabrino, ${ }^{a}$ Cynthia P. Demicheli, ${ }^{a}$ Frédéric J. G. Frezard ${ }^{b}$ and \\ Letícia M. Costa ${ }^{\circledR *, a}$
}

\author{
${ }^{a}$ Departamento de Química, Instituto de Ciências Exatas, Universidade Federal de Minas Gerais, \\ Avenida Antônio Carlos, 6627, Pampulha, 31270-901 Belo Horizonte-MG, Brazil \\ ${ }^{b}$ Departamento de Fisiologia e Biofísica, Universidade Federal de Minas Gerais, \\ Av. Antônio Carlos, 6627, Pampulha, 31270-901 Belo Horizonte-MG, Brazil
}

\begin{abstract}
This study proposes a procedure for speciation of antimony by hydride generation atomic absorption spectrometry in pentavalent antimony drugs. The $\mathrm{Sb}^{\mathrm{III}}$ content was determined by selective generation of $\mathrm{SbH}_{3}$ in medium with higher $\mathrm{Sb}^{\mathrm{V}}$ concentration using 4 to 20-fold lower citric acid solutions than recommended in the available literature. The multivariate optimization of the methods was performed through factorial design followed by a central composite design (CCD). The limit of detection (LOD) and limit of quantification (LOQ) were calculated at 0.15 and $0.05 \mu \mathrm{g} \mathrm{L} \mathrm{L}^{-1}$ and 0.48 and $0.17 \mu \mathrm{g} \mathrm{\textrm {L } ^ { - 1 }}$, for total $\mathrm{Sb}$ and $\mathrm{Sb}^{\mathrm{III}}$, respectively. The relative standard deviation (RSD) values ranged from 3.1 to $19.6 \%$ and 9.1 to $20.1 \%$, while recovery ranged from 95.6 to $102.3 \%$ and 89.1 to $108.1 \%$, for total $\mathrm{Sb}$ and $\mathrm{Sb}^{\mathrm{III}}$, respectively. This method was applied for the analysis of meglumine antimoniate samples. Total $\mathrm{Sb}$ and $\mathrm{Sb}^{\mathrm{III}}$ concentrations ranged from 79.2 to $101.1 \mathrm{mg} \mathrm{mL}^{-1}$ and 0.08 to $0.41 \mathrm{mg} \mathrm{mL}^{-1}$, respectively.
\end{abstract}

Keywords: antimony speciation, leishmaniosis, meglumine antimoniate, citric acid, multivariate optimization

\section{Introduction}

In the group of neglected infectious diseases, leishmaniasis presents itself as a major challenge, accounting for a yearly estimated 700,000-1,000,000 new cases and 26,000-65,000 deaths in the world. ${ }^{1}$ It is caused by leishmania protozoa, transmitted by the bite of infected female phlebotomine sandflies, and largely manifested as cutaneous (CL), mucocutaneous (MCL) and visceral (VL) leishmaniasis. The latter alone displays a mortality rate of non-treatable patients around $95 \%$. $^{1}$

The first successful Brazilian treatment for cutaneous leishmaniasis was reported by Gaspar Vianna. ${ }^{2-6}$ His treatment employed intravenous injections of trivalent $\mathrm{Sb},{ }^{2-6}$ which were substituted a few years later by less toxic pentavalent antimony complexes as stibamine urea, the first of several safer pentavalent antimonials which remained the basis for all leishmaniasis treatments. ${ }^{4,5}$ Two of these complexes, the antimony sodium gluconate and meglumine

*e-mail: leticia@qui.ufmg.br, lemalta41@gmail.com antimoniate (MA), were exploited since the 1940s and are still the most widely used drugs. ${ }^{3-6}$

Nevertheless, antimonial therapy often requires close medical supervision, demanding parenteral injections for local pain and causing systemic side effects such as nausea, vomiting, weakness, myalgia, abdominal cramps, diarrhea, rash, hepatotoxicity and cardiotoxicity. ${ }^{5-7}$ Generally, antimony drugs should be administered parenterally daily (typically $20 \mathrm{mg} \mathrm{Sb} \mathrm{kg}^{-1}$ per day for 20-30 days, not exceeding $850 \mathrm{mg}$ of $\mathrm{Sb}),{ }^{4-6}$ but their toxicity mechanisms remain undiscovered. Even so, for pentavalent antimonials, $\mathrm{Sb}^{\text {III }}$ present as residues or produced through tissue reduction ${ }^{8-12}$ is widely accepted as the responsible for side effects, antileishmanial action and drug resistance. ${ }^{6,13}$ In fact, studies of the cytotoxicity mechanism of the emetic tartar suggest that $\mathrm{Sb}^{\mathrm{III}}$ not only depletes intracellular glutathione and inhibits glutathione reductase, compromising the thiol homeostasis, ${ }^{12,14,15}$ but also increases oxidative stress and reactive oxygen species (ROS), leading to apoptosis. ${ }^{12,15-17}$

Meglumine antimoniate (MA) may be synthesized from $\mathrm{KSb}(\mathrm{OH})_{6}$ or $\mathrm{SbCl}_{5}^{18}$ through two different synthetic 
routes which furnish compounds with lower in vitro cytotoxicity ${ }^{19}$ or even no significant histological changes or increased apoptotic activity in rats ${ }^{13}$ when compared to commercial MA. Considering that MA efficacy is related to the concentration of $\mathrm{Sb}^{\mathrm{V}}$ and its toxicity may be related to the presence of $\mathrm{Sb}^{\mathrm{III}}$ as a contaminant, it is important to determine the concentration of these two species as minimum quality parameters for drugs used in leishmaniasis treatment.

Hydride generation (HG) associated with atomic absorption spectrometry is a powerful tool for total $\mathrm{Sb}$ and $\mathrm{Sb}^{\mathrm{III}}$ speciation at concentrations in the $\mu \mathrm{g} \mathrm{\textrm {L } ^ { - 1 }}$ range, ${ }^{20,21}$ as well as hydride generation-inductively coupled plasma optical emission spectrometry (HG-ICP OES) ${ }^{22}$ Inorganic antimony speciation usually occurs in two steps: first, a sample portion is used to determine total antimony in which the $\mathrm{Sb}^{\mathrm{V}}$ is reduced to the $\mathrm{Sb}^{\mathrm{III}}$ oxidation state using a reducing agent, such as L-cysteine, thiourea, potassium iodide and potassium bromide. ${ }^{23}$ Subsequently, another portion of the sample is subjected to $\mathrm{Sb}^{\mathrm{III}}$ determination in the presence of citrate, which forms a strong complex with $\mathrm{Sb}^{\mathrm{V}}$ but does not react with $\mathrm{Sb}^{\mathrm{III}}$. ${ }^{1-23}$ However, the use of citric acid may contribute to the memory effect, requiring a blank reading at each $\mathrm{Sb}^{\mathrm{III}}$ determination, ${ }^{21}$ as well as causing severe contamination of the inner wall of the $\mathrm{T}$ quartz cell, requiring periodic cleaning by immersion in a nitric acid/hydrofluoric solution to maintain sensitivity. ${ }^{21,22}$

The goal of this work was to develop a simple and fast procedure applied to inorganic antimony speciation in MA drugs used in the treatment of leishmaniasis, which consisted of the development of two HG-AAS analysis methods: total antimony using a reducing agent; and antimony(III) in the presence of citrate. The procedures were optimized by resorting to a full factorial design and central composite design (CCD) ${ }^{24,25}$ Multivariate strategy allows the mapping of the experimental domain using a smaller number of experiments compared to a univariate methodology. Understanding the main factors and their interactions permitted the development of a mathematical model to predict instrumental response.

\section{Experimental}

\section{Instrumentation}

A SpectrAA-240 flame atomic absorption spectrometer (FAAS) (Agilent Technologies, Santa Clara, USA) equipped with a VGA-77 continuous flow hydride generator accessory was used. FAAS operating conditions were: wavelength, $217.6 \mathrm{~nm}$; spectral resolution, $0.5 \mathrm{~nm}$; lamp current, $7 \mathrm{~mA}$; and acetylene and air flow rates, 2.1 and
13.5 $\mathrm{L} \mathrm{min}^{-1}$, respectively. High purity argon was used as purge gas at a flow rate of $90 \mathrm{~mL} \mathrm{~min}^{-1}$. A quartz tube cell was heated under the flame and used for Sb atomization. A sketch of the HG system is shown in Figure 1. The multivariate optimization process was performed using Statistica version $10{ }^{26}$

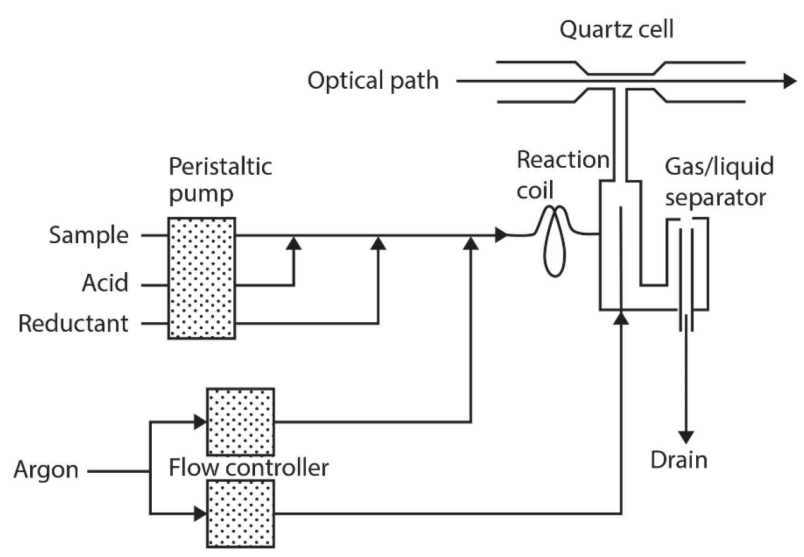

Figure 1. Operation scheme of Agilent Technologies model VGA 77 continuous flow hydride generator system.

\section{Reagents and solutions}

In the preparation of aqueous solutions, ultrapure water was used, obtained with a Direct-Q 3 system (Millipore, Burlington, USA) with resistivity of $18.2 \mathrm{M} \Omega \mathrm{cm}$. All materials, glassware and sample containers used throughout this work were previously cleaned in $10 \%\left(\mathrm{v} \mathrm{v}^{-1}\right)$ nitric acid solution (Merck, Rio de Janeiro, Brazil), immersed in acid bath for $16 \mathrm{~h}$, rinsed with deionized water and dried in a dust free environment. A stock solution containing $1000 \mathrm{mg} \mathrm{L}^{-1} \mathrm{Sb}^{\mathrm{V}}$ was prepared by diluting $0.1091 \mathrm{~g}$ of $\mathrm{KSb}(\mathrm{OH})_{6}$ (Sigma-Aldrich, St. Louis, USA) in $50.0 \mathrm{~mL}$ of $5 \%\left(\mathrm{~m} \mathrm{v}^{-1}\right) \mathrm{HCl}$ (SigmaAldrich, St. Louis, USA), and a standard stock solution containing $500 \mathrm{mg} \mathrm{L}^{-1} \mathrm{Sb}^{\mathrm{III}}$ was prepared by dissolving $0.1385 \mathrm{~g}$ of $\mathrm{K}_{2}\left(\mathrm{C}_{4} \mathrm{H}_{2} \mathrm{O}_{6} \mathrm{Sb}\right)_{2} .3 \mathrm{H}_{2} \mathrm{O}$ (Neon Comercial Ltda, São Paulo, Brazil) in $50.0 \mathrm{~mL}$ of $0.05 \mathrm{~mol} \mathrm{~L}^{-1}$ citric acid (Neon Comercial Ltda, São Paulo, Brazil). Intermediate standards were prepared daily by diluting aliquots of the stock solution with ultra-pure water. The tetrahydroborate solution was prepared daily by dissolving solid $\mathrm{NaBH}_{4}$ (Vetec Quimica Fina Ltda, Rio de Janeiro, Brazil) and $\mathrm{NaOH}$ (Isofar Ltda, Capivari, Brazil) in water. A mixture of $\mathrm{HCl}$ (Sigma-Aldrich, St. Louis, USA), KI (Êxodo Científica, Sumaré, Brazil) and ascorbic acid (Carlo Erba Reagents, Vexin, France) were used as working solutions for total $\mathrm{Sb}$ determination, and citric acid (Neon Comercial Ltda, São Paulo, Brazil) was used to prepare the working solution for $\mathrm{Sb}^{\mathrm{III}}$ determination. 


\section{Samples}

Three commercial MA samples (CMA1-CMA3) from different lots and four synthetic MA samples (SMA1SMA-4), synthesized using the procedure described by Demicheli et al., ${ }^{18}$ were used in this work. The SMA1 and SMA2 formulations were prepared using $\mathrm{SbCl}_{5}$ as a pentavalent antimony source, while SMA3 and SMA4 samples were synthesized using $\mathrm{KSb}(\mathrm{OH})_{6}$. Commercial and synthetic samples had a nominal concentration of 81 and $87 \mathrm{mg} \mathrm{mL}^{-1}$ of $\mathrm{Sb}^{\mathrm{V}}$ in aqueous solution, respectively. Samples were diluted with water and working solutions were prepared daily before use. The dilution factor used were 22,500,000 for Sb total and 275,000 for $\mathrm{Sb}^{\text {III }}$. Total $\mathrm{Sb}$ and $\mathrm{Sb}^{\mathrm{III}}$ determinations of samples were performed under optimized conditions.

\section{Procedure}

In the screening stage, factorial design was made based on some studies in the literature, ${ }^{20,21}$ and on the conditions recommended by the equipment manufacturer. Central composite design (CCD) is a response surface methodology (RSM) used to find optimal conditions of the factors or variables. Analysis of variance (ANOVA) at 0.05 significance level was employed to identify significant factors and interaction effects. The validation of the models was determined by comparing the variance of the lack of fit (lof) and the pure experimental error (pe) with the values of the Fisher distribution $(F$-test, $p=0.05) .{ }^{24,25}$ Experiments were conducted in randomized order.

For total $\mathrm{Sb}$ determination, all species of $\mathrm{Sb}^{\mathrm{V}}$ shall be converted to $\mathrm{Sb}^{\text {III }}$ by the addition of an analytical standard (or MA sample) aliquot to a working solution containing

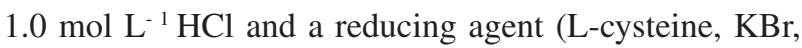
thiourea and KI were previously tested). Potassium iodide was the reducing agent selected in the experimental design. It allows better instrumental responses, and ascorbic acid was added to stabilize the working solution. Hydrochloric acid and a mixture of $\mathrm{NaBH}_{4}$ and $\mathrm{NaOH}$ was used in the acid channel and in the reducer channel of the VGA-77 accessory, respectively (Figure 1). To evaluate the signal intensity in the method optimization, working solutions were fortified with $5.0 \mu \mathrm{g} \mathrm{L}^{-1} \mathrm{Sb}^{\mathrm{V}}$.

For the selective determination of $\mathrm{Sb}^{\mathrm{III}}$, an analytical standard (or MA sample) aliquot should be added to a working solution containing citric acid that forms a stable complex with the present $\mathrm{Sb}^{\vee}$ and does not allow it to form hydrides and interfere with the $\mathrm{Sb}^{\mathrm{III}}$ signal. Citric acid also is responsible for reacting with borohydride to provide hydrogen for the stibin formation reaction $\left(\mathrm{SbH}_{3}\right)$.
Therefore, it was used in the acid channel at the same concentration as the working solution while a mixture of $\mathrm{NaBH}_{4}$ and $\mathrm{NaOH}$ was used in the reducing channel of the VGA-77 accessory (Figure 1). To evaluate the selective determination of $\mathrm{Sb}^{\mathrm{III}}$ and to verify the occurrence of signals related to $\mathrm{Sb}^{\mathrm{v}}$, in each trial of the experimental designs two working solutions were analyzed, one containing $5.0 \mu \mathrm{g} \mathrm{L}^{-1}$

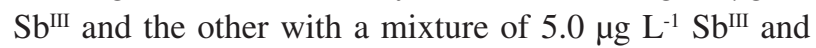
$400.0 \mu \mathrm{g} \mathrm{L}^{-1} \mathrm{Sb}^{\mathrm{V}}$.

\section{Results and Discussion}

\section{Optimization of the total Sb determination method}

Initially, a $2^{4}$ full factorial design with center point (CP) were evaluated: KI concentration [1.0(-); 5.5(0) and $10.0(+)$, in percentage $\left.\left(\mathrm{m} \mathrm{v}^{-1}\right)\right] ; \mathrm{NaBH}_{4}$ concentration $\left[0.6(-) ; 1.3(0)\right.$ and $2.0(+)$, in percentage $\left.\left(\mathrm{m} \mathrm{v}^{-1}\right)\right] ; \mathrm{HCl}$ concentration used in the acid channel $[5.0(-) ; 7.5(0)$ and $\left.10.0(+), \mathrm{mol} \mathrm{L}^{-1}\right]$, and the contact time of the analyte with the working solution $(0(-) ; 60(0)$ and $120(+)$, s). Pareto's chart (Figure 2) shows that the variables $\left[\mathrm{NaBH}_{4}\right],[\mathrm{KI}]$ and contact time had a significant effect on instrumental response at $95 \%$ confidence level. The negative sign of the effects denotes that the use of lower $\mathrm{NaBH}_{4}$ and $\mathrm{KI}$ concentrations led to an increase of the instrumental response, and the positive sign shows an increase in the response using the contact time $(p=0.05)$.

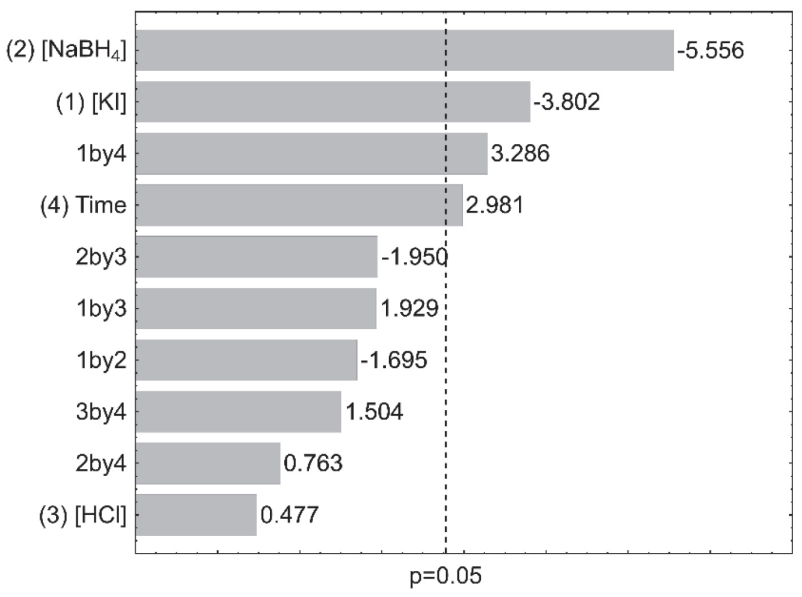

Figure 2. Pareto's chart obtained from factorial design $2^{4}$ with central point $(\mathrm{CP})$ for total $\mathrm{Sb}$ determination by HG-AAS.

A matrix experiments of central composite design (CCD) (Table 1) was performed to evaluate the previously selected significant factors $(\mathrm{HCl}$ concentration was set at $5.0 \mathrm{~mol} \mathrm{~L}^{-1}$ ).

The optimal values obtained by deriving the mathematical equations 1,2 and 3 obtained by this 
Table 1. Matrix experiments of central composite design (CCD) for total $\mathrm{Sb}$ determination by HG-AAS; values in parentheses are the coded values

\begin{tabular}{|c|c|c|c|c|}
\hline Assay & $\begin{array}{c}{[\mathrm{KI}] /} \\
\left(\%, \mathrm{~m} \mathrm{v}^{-1}\right)\end{array}$ & $\begin{array}{l}{\left[\mathrm{NaBH}_{4}\right] /} \\
\left(\%, \mathrm{~m} \mathrm{v}^{-1}\right)\end{array}$ & time / s & $\begin{array}{c}\text { Integrated } \\
\text { absorbance }\end{array}$ \\
\hline 1 & $0.8(-1)$ & $0.7(-1)$ & $25(-1)$ & 0.1916 \\
\hline 2 & $0.8(-1)$ & $0.7(-1)$ & $95(+1)$ & 0.1728 \\
\hline 3 & $0.8(-1)$ & $1.1(+1)$ & $25(-1)$ & 0.2385 \\
\hline 4 & $0.8(-1)$ & $1.1(+1)$ & $95(+1)$ & 0.1601 \\
\hline 5 & $1.6(+1)$ & $0.7(-1)$ & $25(-1)$ & 0.2036 \\
\hline 6 & $1.6(+1)$ & $0.7(-1)$ & $95(+1)$ & 0.1788 \\
\hline 7 & $1.6(+1)$ & $1.1(+1)$ & $25(-1)$ & 0.1916 \\
\hline 8 & $1.6(+1)$ & $1.1(+1)$ & $95(+1)$ & 0.1418 \\
\hline 9 & $0.5(-\alpha)$ & $0.9(0)$ & $60(0)$ & 0.1973 \\
\hline 10 & $1.9(+\alpha)$ & $0.9(0)$ & $60(0)$ & 0.1675 \\
\hline 11 & $1.2(0)$ & $0.6(-\alpha)$ & $60(0)$ & 0.2107 \\
\hline 12 & $1.2(0)$ & $1.2(+\alpha)$ & $60(0)$ & 0.1678 \\
\hline 13 & $1.2(0)$ & $0.9(0)$ & $0(-\alpha)$ & 0.1944 \\
\hline 14 & $1.2(0)$ & $0.9(0)$ & $120(+\alpha)$ & 0.2002 \\
\hline $\mathrm{CP}$ & $1.2(0)$ & $0.9(0)$ & $60(0)$ & 0.1953 \\
\hline $\mathrm{CP}$ & $1.2(0)$ & $0.9(0)$ & $60(0)$ & 0.1929 \\
\hline $\mathrm{CP}$ & $1.2(0)$ & $0.9(0)$ & $60(0)$ & 0.2043 \\
\hline $\mathrm{CP}$ & $1.2(0)$ & $0.9(0)$ & $60(0)$ & 0.2064 \\
\hline $\mathrm{CP}$ & $1.2(0)$ & $0.9(0)$ & $60(0)$ & 0.1825 \\
\hline
\end{tabular}

CP: central point; $\alpha=1.682$.

design were: $\mathrm{KI}$ concentration $=1.00 \%\left(\mathrm{~m} \mathrm{v}^{-1}\right) ; \mathrm{NaBH}_{4}$ concentration $=0.90 \%\left(\mathrm{~m} \mathrm{v}^{-1}\right)$ and contact time $=40 \mathrm{~s}$.

$$
\begin{aligned}
& Z=-0.0071 \mathrm{~A}-0.0058 \mathrm{~A}^{2}-0.0064 \mathrm{~B}-0.0033 \mathrm{~B}^{2}- \\
& 0.0104 \mathrm{AB} \\
& Z=-0.071 \mathrm{~A}-0.0053 \mathrm{~A}^{2}-0.0117 \mathrm{D}-0.0028 \mathrm{AD} \\
& Z=-0.0063 \mathrm{~B}-0.0024 \mathrm{~B}^{2}-0.0116 \mathrm{D}^{2}-0.0108 \mathrm{BD}
\end{aligned}
$$

where, Z: instrumental response in integrated absorbance; A: KI concentration; $\mathrm{B}: \mathrm{NaBH}_{4}$ concentration; $\mathrm{C}: \mathrm{HCl}$ concentration used in the acid channel and D: contact time of the analyte with the working solution.

\section{Optimization of the Sb"I determination method}

To optimize the analytical conditions for $\mathrm{Sb}^{\text {III }}$ determination by HG-AAS, three factors were initially evaluated using a $2^{3}$ factorial design with CP (Table 2): concentration of citric acid used in the working solution and in the acid channel; $\mathrm{NaBH}_{4}$ concentration and analyte contact time with the working solution. During the experiments, the T quartz cell capillary became clogged due to the use of high citric acid concentrations in some assays. Therefore, it was necessary to interrupt the quantification to clean the T quartz cell by immersion in nitric/hydrofluoric acid solution for $30 \mathrm{~s}$. This indicates that high concentration of citric acid should be avoided, to increase lifetime of the T cell. The Pareto's chart (Figure 3) shows that the variables $\left[\mathrm{NaBH}_{4}\right]$ and [citric acid] had a significant effect on instrumental response at $95 \%$ confidence level. The signs of effects indicated that increasing $\mathrm{NaBH}_{4}$ concentration and decreasing citric acid concentration affected the instrumental response $(p=0.05)$.

Table 2. Matrix experiments of factorial design $2^{3}$ with $\mathrm{CP}$ for $\mathrm{Sb}^{\mathrm{II}}$ determination by HG-AAS; values in parentheses are the coded values

\begin{tabular}{lccccc}
\hline Assay & $\begin{array}{c}{[\mathrm{CA}]^{\mathrm{a}} /} \\
\left(\%, \mathrm{~m} \mathrm{v}^{-1}\right)\end{array}$ & $\begin{array}{c}{\left[\mathrm{NaBH}_{4}\right] /} \\
\left(\%, \mathrm{~m} \mathrm{v}^{-1}\right)\end{array}$ & time / s & $\mathrm{IA}^{\mathrm{b}}$ & $\mathrm{IA}^{\mathrm{c}}$ \\
\hline 1 & $4(-)$ & $0.6(-)$ & $0(-)$ & 0.1854 & 0.1812 \\
2 & $20(+)$ & $0.6(-)$ & $0(-)$ & 0.0979 & 0.1043 \\
3 & $4(-)$ & $2.0(+)$ & $0(-)$ & 0.1846 & 0.1921 \\
4 & $20(+)$ & $2.0(+)$ & $0(-)$ & 0.2315 & 0.1633 \\
5 & $4(-)$ & $0.6(-)$ & $120(+)$ & 0.1870 & 0.1881 \\
6 & $20(+)$ & $0.6(-)$ & $120(+)$ & 0.1222 & 0.1286 \\
7 & $4(-)$ & $2.0(+)$ & $120(+)$ & 0.1837 & 0.1885 \\
8 & $20(+)$ & $2.0(+)$ & $120(+)$ & 0.1753 & 0.1791 \\
$\mathrm{CP}$ & $12(0)$ & $1.3(0)$ & $60(0)$ & 0.1779 & 0.2103 \\
$\mathrm{CP}$ & $12(0)$ & $1.3(0)$ & $60(0)$ & 0.1777 & 0.1637 \\
$\mathrm{CP}$ & $12(0)$ & $1.3(0)$ & $60(0)$ & 0.1872 & 0.2030 \\
$\mathrm{CP}$ & $12(0)$ & $1.3(0)$ & $60(0)$ & 0.1955 & 0.2018 \\
$\mathrm{CP}$ & $12(0)$ & $1.3(0)$ & $60(0)$ & 0.1826 & 0.2023 \\
\hline
\end{tabular}

${ }^{a}$ Citric acid concentration; integrated absorbance in presence of $5 \mu \mathrm{g} \mathrm{L}{ }^{-1}$ of $\mathrm{Sb}^{\mathrm{III}}$; cintegrated absorbance in presence of $5 \mu \mathrm{L} \mathrm{L}^{-1}$ of Sb${ }^{\mathrm{II}}$ and $400 \mu \mathrm{g} \mathrm{L}^{-1}$ of $\mathrm{Sb}^{\mathrm{v}}$. CP: central point.

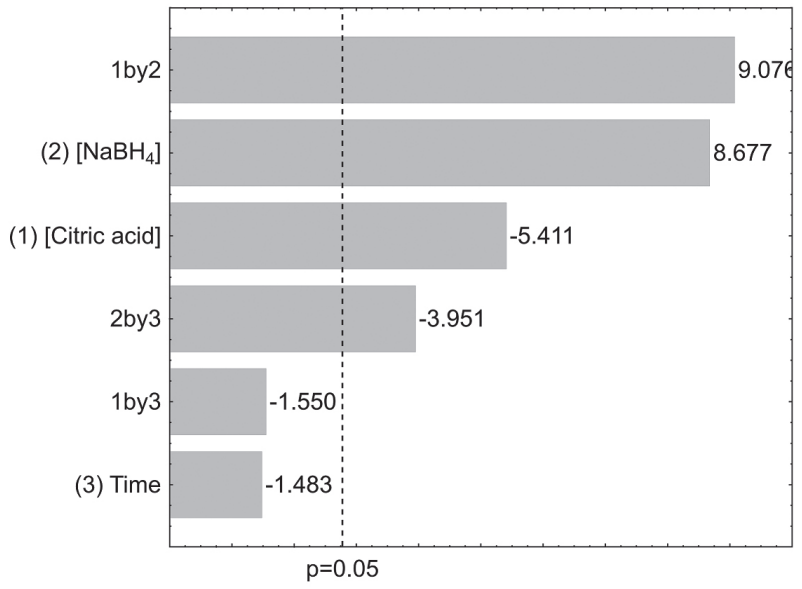

Figure 3. Pareto's chart obtained from factorial design $2^{3}$ with $\mathrm{CP}$ for $\mathrm{Sb}^{\mathrm{III}}$ determination by HG-AAS.

On the other hand, the interaction between these two factors had a positive effect on the response. Therefore, increasing the concentration of one reagent while 
Table 3. Matrix experiments of central composite design (CCD) for $\mathrm{Sb}^{\mathrm{III}}$ determination by HG-AAS

\begin{tabular}{|c|c|c|c|c|c|c|c|c|c|c|}
\hline \multirow{2}{*}{ Assay } & \multicolumn{4}{|c|}{$[$ Citric acid $] /\left(\%, \mathrm{~m} \mathrm{v}^{-1}\right)$} & \multicolumn{4}{|c|}{$\left[\mathrm{NaBH}_{4}\right] /\left(\%, \mathrm{~m} \mathrm{v}^{-1}\right)$} & \multirow{2}{*}{$\begin{array}{l}\text { Integrated } \\
\text { absorbance }^{\mathrm{a}}\end{array}$} & \multirow{2}{*}{$\begin{array}{l}\text { Integrated } \\
\text { absorbance }^{\mathrm{b}}\end{array}$} \\
\hline & $1^{\mathrm{st}}$ & $2^{\text {nd }}$ & $3^{\text {rd }}$ & $4^{\text {th }}$ & $1^{\mathrm{st}}$ & $2^{\text {nd }}$ & $3^{\text {rd }}$ & $4^{\text {th }}$ & & \\
\hline 1 & 2.0 & 1.0 & 1.0 & 0.6 & 3.0 & 2.0 & 1.6 & 1.0 & 0.2425 & 0.2479 \\
\hline 2 & 6.0 & 4.0 & 2.0 & 1.0 & 3.0 & 2.0 & 1.6 & 1.0 & 0.2240 & 0.2325 \\
\hline 3 & 2.0 & 1.0 & 1.0 & 0.6 & 1.0 & 1.0 & 1.0 & 0.8 & 0.2436 & 0.2632 \\
\hline 4 & 6.0 & 4.0 & 2.0 & 1.0 & 1.0 & 1.0 & 1.0 & 0.8 & 0.2462 & 0.2513 \\
\hline 5 & 1.2 & 0.4 & 0.8 & 0.5 & 2.0 & 1.5 & 1.3 & 0.9 & 0.2351 & 0.2726 \\
\hline 6 & 4.0 & 2.5 & 1.5 & 0.8 & 3.4 & 2.2 & 1.7 & 1.1 & 0.2426 & 0.2676 \\
\hline 7 & 6.8 & 4.6 & 2.2 & 1.1 & 2.0 & 1.5 & 1.3 & 0.9 & 0.2458 & 0.2591 \\
\hline 8 & 4.0 & 2.5 & 1.5 & 0.8 & 0.6 & 0.8 & 0.9 & 0.7 & 0.2443 & 0.2573 \\
\hline $\mathrm{CP}$ & 4.0 & 2.5 & 1.5 & 0.8 & 2.0 & 1.5 & 1.3 & 0.9 & 0.2452 & 0.2666 \\
\hline $\mathrm{CP}$ & 4.0 & 2.5 & 1.5 & 0.8 & 2.0 & 1.5 & 1.3 & 0.9 & 0.2692 & 0.2749 \\
\hline $\mathrm{CP}$ & 4.0 & 2.5 & 1.5 & 0.8 & 2.0 & 1.5 & 1.3 & 0.9 & 0.2519 & 0.2684 \\
\hline $\mathrm{CP}$ & 4.0 & 2.5 & 1.5 & 0.8 & 2.0 & 1.5 & 1.3 & 0.9 & 0.2504 & 0.2624 \\
\hline $\mathrm{CP}$ & 4.0 & 2.5 & 1.5 & 0.8 & 2.0 & 1.5 & 1.3 & 0.9 & 0.2452 & 0.2666 \\
\hline
\end{tabular}

antegrated absorbance of $4^{\text {th }} \mathrm{CCD}$ in the presence of $5 \mu \mathrm{g} \mathrm{L}{ }^{-1} \mathrm{Sb}^{\mathrm{III}}$; bintegrated absorbance of $4^{\text {th }} \mathrm{CCD}$ in the presence of $5 \mu \mathrm{g} \mathrm{L}{ }^{-1} \mathrm{Sb}^{\mathrm{III}}$ and $400 \mu \mathrm{g} \mathrm{L}{ }^{-1} \mathrm{Sb}^{\mathrm{V}}$. CP: central point.

decreasing the concentration of the other will negatively impact the instrumental response. The variation of contact time was not significant, but its interaction with the reduced concentration led to a negative effect on the instrumental response. Based on this assessment, the CCD developed were shown in Table 3.

It took at least $100 \mathrm{~s}$ of contact time to suppress the interference from $\mathrm{Sb}^{\mathrm{v}}$ when low concentrations of citric acid were applied, so this time was used in all subsequent experiments. As can be seen in Figure 4a, the response surface showed two trends, so in a second CCD (Table 3 ) we chose to explore the region in which lower concentrations of reagents were used. The response surface obtained in Figure $4 \mathrm{~b}$ shows a maximum absorbance point for coordinates $1.2 \%\left(\mathrm{~m} \mathrm{v}^{-1}\right)$ and $1.5 \%\left(\mathrm{~m} \mathrm{v}^{-1}\right)$, referring to the $\mathrm{NaBH}_{4}$ and citric acid concentration values, respectively. However, the model presented a lack of fit, so we decided to perform a third CCD experiment with the optimal concentration values obtained at the central point (Table 3 ). The model indicated a trend of higher sensitivity in two different directions again (Figure 4c), so following the same reasoning, we chose to explore the region of lowest reagent concentration values in a fourth $\mathrm{CCD}$ experiment (Table 3). The analysis of the response surface obtained (Figure 4d) showed that the highest absorbance values were obtained in the intermediate regions, especially at the point with concentration values of $1.0 \%\left(\mathrm{~m} \mathrm{v}^{-1}\right)$ and $0.8 \%\left(\mathrm{~m} \mathrm{v}^{-1}\right)$ for citric acid and $\mathrm{NaBH}_{4}$ respectively, selected for the optimization.

\section{Interference study}

The working solutions containing the analytes and potentially interfering ions were analyzed by applying the optimized methods. Previous analysis of some commercial MA samples showed the presence of $\mathrm{As}, \mathrm{Cu}$ and $\mathrm{Pb}$ as contaminants. ${ }^{27}$ Although small amounts of nickel were detected $\left(<0.3 \mathrm{mg} \mathrm{L}^{-1}\right)$ in undiluted commercial samples, this element was also included in the interference study due to its strong effect on $\mathrm{Sb}$ measurements by HG-AAS. ${ }^{27}$ The selectivity of the methods was evaluated by preparing working solutions contaminated with $3.5 \mu \mathrm{g} \mathrm{L}^{-1} \mathrm{Sb}^{\mathrm{v}}$ or $1.5 \mu \mathrm{g} \mathrm{L}{ }^{-1} \mathrm{Sb}^{\mathrm{II}}$ for total $\mathrm{Sb}$ and $\mathrm{Sb}^{\mathrm{III}}$ determination methods, respectively. Another group of working solutions containing the same amounts of $\mathrm{Sb}^{\mathrm{V}}$ or $\mathrm{Sb}^{\mathrm{III}}$ were also contaminated with $20 \mu \mathrm{g} \mathrm{L}^{-1}$ of interfering $\mathrm{Ni}^{\mathrm{II}}, \mathrm{Pb}^{\mathrm{II}}, \mathrm{Cu}^{\mathrm{II}}$ or $\mathrm{As}^{\mathrm{III}}$, as well as $400 \mu \mathrm{g} \mathrm{L}^{-1}$ of $\mathrm{Sb}^{\mathrm{V}}$ for the $\mathrm{Sb}^{\mathrm{III}}$ determination method. Each of the solutions with or without interfering elements was prepared in independent triplicates, and the results were compared using $95 \%$ confidence level hypothesis tests ( $F$-test and $t$-test). No interference was observed in $\mathrm{Sb}$ signals at the studied concentrations. Using $1.0 \%\left(\mathrm{~m} \mathrm{v}^{-1}\right)$ citric acid, it was possible to selectively detect $\mathrm{Sb}^{\mathrm{II}}$ in the presence of 8,000-fold $\mathrm{Sb}^{\mathrm{v}}$, while Flores et al..$^{20,21}$ observed this selective detection in the presence of 947 -fold $\mathrm{Sb}^{\mathrm{V}}$ using 20\% ( $\left.\mathrm{m} \mathrm{v}^{-1}\right)$ citric acid, and selective quantification of $\mathrm{Sb}^{\mathrm{III}}$ was possible in the presence of 2,350-fold $\mathrm{Sb}^{\mathrm{V}}$, while the authors obtained this selective quantification in the presence of 1,300-fold $\mathrm{Sb}^{\mathrm{V}}$ using $4 \%\left(\mathrm{~m} \mathrm{v}^{-1}\right)$ citric acid. 
(a)

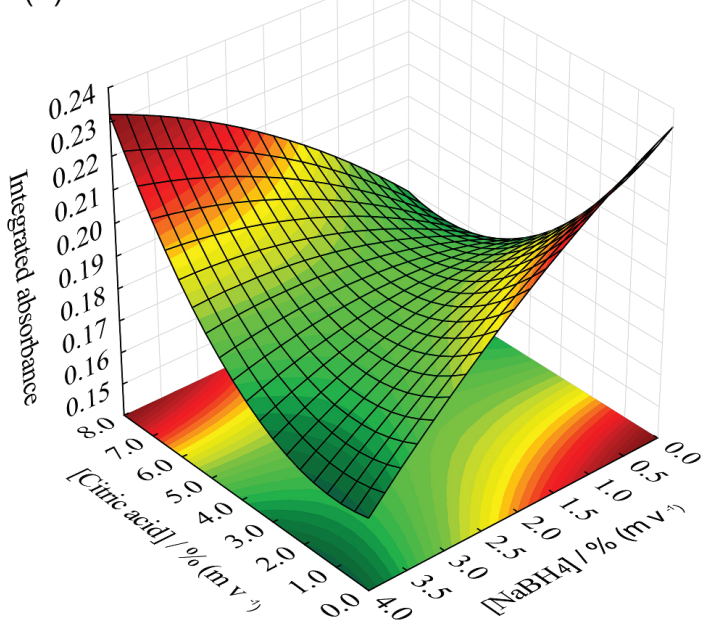

(c)

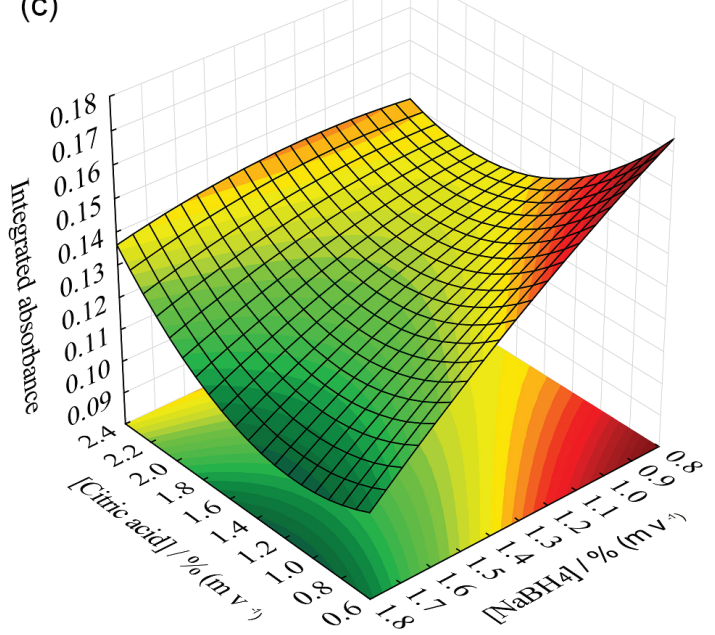

(b)

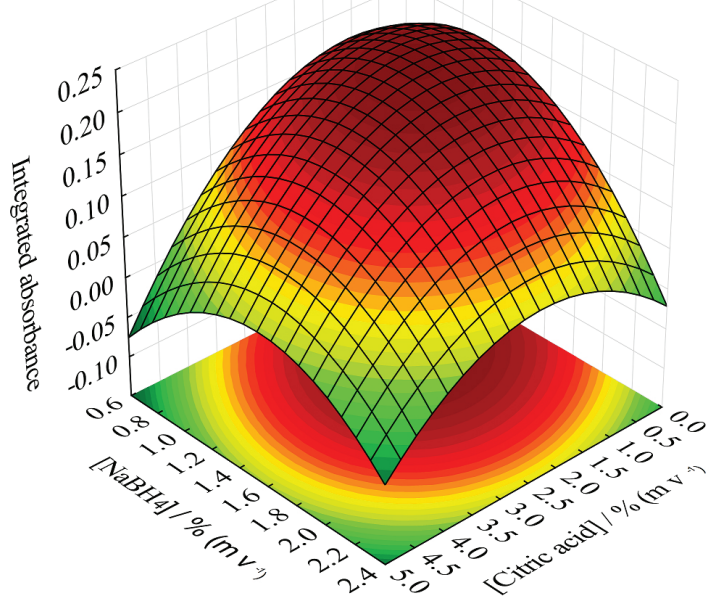

(d)

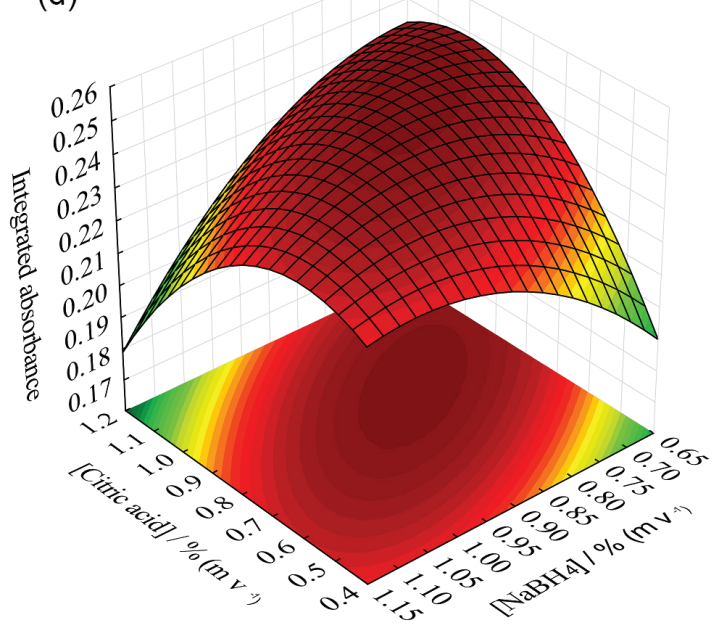

Figure 4. Response surface plots obtained from CCDs for $\mathrm{Sb}^{\text {III }}$. (a) $1^{\text {st }} \mathrm{CCD}$; (b) $2^{\text {nd }} \mathrm{CCD}$; (c) $3^{\text {rd }} \mathrm{CCD}$ and (d) $4^{\text {th }} \mathrm{CCD}$.

\section{Validation of the proposed method}

In order to demonstrate that the analytical method produced reliable results and is suitable for the intended purpose, we subjected the optimized method to systematic evaluation by the experimental tests for validation indicated by the main guide used in Brazil. ${ }^{28}$

Linearity was verified according to the procedures proposed by de Souza and Junqueira. ${ }^{29}$ To estimate the linear regression parameters, the ordinary least squares (OLS) method was used. Six equally spaced points (to avoid leverage points) were used to plot the analytical curves, and readings were taken randomly. The concentration ranges chosen for evaluation of the calibration curves linearity were 0.0 to $8.0 \mu \mathrm{g} \mathrm{L}^{-1}$ and 0.0 to $3.7 \mu \mathrm{g} \mathrm{L} \mathrm{L}^{-1}$ for the total $\mathrm{Sb}$ and $\mathrm{Sb}^{\mathrm{III}}$ determination methods, respectively. The Jackknife test was performed to detect and remove outliers. The verification that regression residuals were normally distributed, independent and homoscedastic was confirmed by the Ryan-Joiner coefficients of 0.9856 and 0.9787, Durbin-Watson statistics of 1.67 and 1.56, and $\mathrm{t}$-Levene statistics of 0.166 and 0.223 for the total $\mathrm{Sb}$ and $\mathrm{Sb}^{\mathrm{III}}$ determination methods, respectively. The linearity of the model was confirmed by ANOVA, which revealed that the regression was significant while the lack of fit was not significant. All statistical tests were performed with a $95 \%$ confidence level $(p=0.05)$.

The limits of detection (LOD) and quantification (LOQ) were calculated by measuring seven independently prepared blank analytical solutions (working solutions without metal). The LODs were calculated at 0.15 and $0.05 \mu \mathrm{g} \mathrm{L}{ }^{-1}$, and the LOQs were measured at 0.48 and $0.17 \mu \mathrm{g} \mathrm{L}^{-1}$ for total $\mathrm{Sb}$ and $\mathrm{Sb}^{\mathrm{III}}$, respectively $(\mathrm{LOD}=\mathrm{LOQ} / 3.3$ and $\mathrm{LOQ}=10 \mathrm{~s} / \mathrm{b}$, where $\mathrm{s}$ is the standard deviation of responses from 7 independent blanks and $b$ is the slope of the analytical curve). 
For repeatability and recovery tests, the sample was fortified at three concentration levels: $0.5 ; 3.5$ and $8.0 \mu \mathrm{g} \mathrm{L}{ }^{-1}$ for $\mathrm{Sb}$ total, and $0.2 ; 1.5$ and $3.5 \mu \mathrm{g} \mathrm{L}^{-1}$ for $\mathrm{Sb}^{\mathrm{III}}$, performing seven independent determinations per level, expressed as the relative standard deviation (RSD) and percentage respectively. The RSD values ranged from 3.1 to $19.6 \%$ and 9.1 to $20.1 \%$, while recovery ranged from 95.6 to $102.3 \%$ and 89.1 to $108.1 \%$, for total $\mathrm{Sb}$ and $\mathrm{Sb}^{\mathrm{III}}$ respectively. These values meet the acceptance criteria suggested by the Association of Official Analytical Chemists (AOAC) for the evaluated concentration ranges, which indicates the repeatability limit of $30 \%$ for the RSD value and the range of 40 to $120 \%$ for the recovery. ${ }^{30}$ Validation results are presented in Table 4.

Table 4. Analytical figures of merit for total $\mathrm{Sb}$ and $\mathrm{Sb}^{\mathrm{III}}$ determinations by HG-AAS

\begin{tabular}{|c|c|c|c|}
\hline Parameter & & $\begin{array}{c}\text { Value } \\
\text { (total Sb) }\end{array}$ & Value $\left(\mathrm{Sb}^{\text {III }}\right)$ \\
\hline Linear range / $\left(\mu \mathrm{g} \mathrm{L} \mathrm{L}^{-1}\right)$ & & $0-8.00$ & $0-3.70$ \\
\hline Slope & & 0.0369 & 0.0602 \\
\hline Intersection & & 0.0065 & 0.0009 \\
\hline $\mathrm{R}^{2}(\mathrm{n}=3)$ & & 0.9959 & 0.9968 \\
\hline $\operatorname{LOD}(\mathrm{n}=7) /\left(\mu \mathrm{g} \mathrm{L}^{-1}\right)$ & & 0.15 & 0.05 \\
\hline $\operatorname{LOQ}(\mathrm{n}=7) /\left(\mu \mathrm{g} \mathrm{L}^{-1}\right)$ & & 0.48 & 0.17 \\
\hline \multirow{3}{*}{$\begin{array}{l}\text { Repeatability by levels } \\
(\mathrm{n}=7) / \% \mathrm{RSD}\end{array}$} & low & 19.6 & 20.1 \\
\hline & middle & 7.3 & 10.1 \\
\hline & high & 3.1 & 9.1 \\
\hline \multirow{3}{*}{$\begin{array}{l}\text { Recovery by levels } \\
(\mathrm{n}=7) / \%\end{array}$} & low & 95.6 & 108.1 \\
\hline & middle & 102.3 & 94.5 \\
\hline & high & 96.5 & 89.1 \\
\hline
\end{tabular}

$\mathrm{R}^{2}$ : coefficient of determination; $\mathrm{n}$ : number of independent replicates; LOD: limit of detection; LOQ: limit of quantification; RSD: relative standard deviation.

Determination of total $\mathrm{Sb}$ and $\mathrm{Sb}^{\text {III }}$ in commercial and synthetic meglumine antimoniate samples

Total $\mathrm{Sb}$ and $\mathrm{Sb}^{\mathrm{III}}$ were determined in commercial and synthetic MA samples using optimized conditions (Table 5). Total Sb concentration in three commercial MA samples lots ranged from 80.1 to $101.1 \mathrm{mg} \mathrm{mL}^{-1}$ (nominal value of $81 \mathrm{mg} \mathrm{mL}^{-1}$ ). In the determination of trivalent $\mathrm{Sb}$ in commercial

MA samples, the results ranged from 0.08 to $0.17 \mathrm{mg} \mathrm{mL}^{-1}$, which corresponds to percentages of 0.08 to $0.21 \%$ of total $\mathrm{Sb}$ in commercial drugs. These results are equivalent to others found in the literature reporting $\mathrm{Sb}^{\mathrm{III}}$ concentrations less than $0.3 \mathrm{mg} \mathrm{mL}^{-1} .{ }^{31-33} \mathrm{In}$ earlier publications, $\mathrm{Sb}^{\mathrm{II}}$ levels in commercial MA ranging from
1.7 to $15.5 \mathrm{mg} \mathrm{mL}^{-1}$ were reported, ${ }^{20,21,34-39}$ suggesting an adaptation in the commercial MA manufacturing process to control pentavalent antimony reduction.

Table 5. Concentration of $\mathrm{Sb}^{\mathrm{III}}$ and total $\mathrm{Sb}$ in commercial and synthetic samples using the HG-AAS proposed procedure. Results are expressed as mean \pm standard deviation $(\mathrm{n}=3)$; values in parentheses are the percentages of $\mathrm{Sb}^{\text {III }}$ out of total $\mathrm{Sb}$

\begin{tabular}{lcc}
\hline Sample & Total Sb $/\left(\mathrm{mg} \mathrm{mL}^{-1}\right)$ & $\mathrm{Sb}^{\mathrm{II}} /\left(\mathrm{mg} \mathrm{mL}^{-1}\right)$ \\
\hline CMA1 & $83.37 \pm 1.89$ & $0.14 \pm 0.01(0.17)$ \\
CMA2 & $80.08 \pm 1.31$ & $0.17 \pm 0.01(0.21)$ \\
CMA3 & $101.1 \pm 2.9$ & $0.08 \pm 0.04(0.08)$ \\
SMA1 & $79.23 \pm 4.16$ & $0.41 \pm 0.01(0.52)$ \\
SMA2 & $82.35 \pm 1.96$ & $0.41 \pm 0.28(0.50)$ \\
SMA3 & $83.59 \pm 2.80$ & $0.11 \pm 0.01(0.14)$ \\
SMA4 & $82.13 \pm 2.16$ & $0.13 \pm 0.02(0.16)$ \\
\hline
\end{tabular}

Four MA formulations were synthesized for this work based on the method described by Demicheli et al. ${ }^{18}$ The SMA1 and SMA2 formulations were prepared using $\mathrm{SbCl}_{5}$ as a pentavalent antimony source, while SMA3 and SMA4 samples were synthesized using $\mathrm{KSb}(\mathrm{OH})_{6}$. There was no significant difference between the amounts of total $\mathrm{Sb}$ found in the four formulations, which were very close to the theoretical value, while the reported $\mathrm{Sb}^{\mathrm{III}}$ content was slightly higher in formulations prepared with $\mathrm{SbCl}_{5}$.

Results in Table 5 indicated that these formulations are suitable in the treatment of leishmaniasis with an adequate amount of $\mathrm{Sb}^{\mathrm{V}}$ and a low content of $\mathrm{Sb}^{\mathrm{II}}$. It should be suggested as an efficient treatment against the disease with low potential of side effects. However, more studies are necessary to support this idea.

\section{Conclusions}

A method for inorganic antimony speciation in meglumine antimoniate samples used in the treatment of leishmaniasis was developed and evaluated.

In the development of the analytical method, the use of multivariate optimization allowed us to reach the condition of higher analytical signal intensity with a reduced number of assays, besides providing information on the interaction between the evaluated variables, which in the $\mathrm{Sb}^{\mathrm{III}}$ determination method development was crucial to find the optimal condition of analysis with the use of a lower citric acid concentration. The use of citric acid at lower concentrations has eliminated problems reported in some publications such as the need for periodic quartz cell cleaning to maintain sensitivity, ${ }^{20,21}$ and the requirement to measure a blank analytical solution after each Sb determination to 
correct memory effects. ${ }^{20}$ Thus, there was no loss in the analytical frequency by one sample per min (45 s of delay and $15 \mathrm{~s}$ of triplicate reading). Even at lower concentrations, citric acid retained the ability to suppress $\mathrm{Sb}^{\mathrm{v}}$ signals present at approximately 2,000-fold higher concentrations than $\mathrm{Sb}^{\mathrm{III}}$.

The methods were able to quantify total $\mathrm{Sb}$ and $\mathrm{Sb}^{\mathrm{III}}$ in commercial and synthetic meglumine antimoniate samples, and may be used in the quality control of these formulations.

\section{Acknowledgments}

We are grateful for the financial support and scholarships from the Coordenação de Aperfeiçoamento de Pessoal de Nível Superior (CAPES) and Conselho Nacional de Desenvolvimento Científico e Tecnológico (CNPq).

\section{References}

1. https://www.who.int/en/news-room/fact-sheets/detail/ leishmaniasis, accessed in July 2020.

2. Berman, J. D.; Rev. Infect. Dis. 1988, 10, 560.

3. Sneader, W.; Drug Discovery: A History, vol. 1, $1^{\text {st }}$ ed.; John Wiley \& Sons Ltd: Chichester, UK, 2005, p. 472.

4. Haldar, A. K.; Sen, P.; Roy, S.; Mol. Biol. Int. 2011, 2011, 571242.

5. Rath, S.; Trivelin, L. A.; Imbrunito, T. R.; Tomazela, D. M.; de Jesús, M. N.; Marzal, P. C.; Quim. Nova 2003, 26, 550.

6. Frézard, F.; Demicheli, C.; Ribeiro, R. R.; Molecules 2009, 14, 2317.

7. Lawn, S. D.; Armstrong, M.; Whitty, C. J.; Trans. R. Soc. Trop. Med. Hyg. 2006, 100, 264.

8. Goyard, S.; Segawa, H.; Gordon, J.; Showalter, M.; Duncan, R.; Turco, S. J.; Beverley, S. M.; Mol. Biochem. Parasitol. 2003, $130,31$.

9. Burguera, J. L.; Burguera, M.; Petit de Peña, Y.; Lugo, A.; Anez, N.; Trace Elem. Med. 1993, 10, 66.

10. Lugo de Yarbuh, A.; Anez, N.; Petit de Peña, Y.; Burguera, J. L.; Burguera, M.; Ann. Trop. Med. Parasitol. 1994, 88, 37.

11. Marquis, N.; Gourbal, B.; Rosen, B. P.; Mukhopadhyay, R.; Ouellette, M.; Mol. Microbiol. 2005, 57, 1690.

12. Ponte-Sucre, A.; Gamarro, F.; Dujardin, J. C.; Barrett, M. P.; López-Vélez, R.; García-Hernández, R.; Pountain, A. W.; Mwenechanya, R.; Papadopoulou, B.; PLoS Neglected Trop. Dis. 2017, 11, e0006052.

13. Kato, K. C.; Morais-Teixeira, E.; Reis, P. G.; Silva-Barcellos, N. M.; Salaüm, P.; Campos, P. P.; Corrêa-Junior, J. D.; Rabello, A.; Demicheli, C.; Frézard, F.; Antimicrob. Agents Chemother 2014, $58,481$.

14. Wyllie, S.; Cunningham, M. L.; Fairlamb, A. H.; J. Biol. Chem. 2004, 279, 39925.
15. Wyllie, S.; Fairlamb, A. H.; Biochem. Pharmacol. 2006, 71, 257.

16. Timerstein, M. A.; Plews, P. I.; Walker, C. V.; Woolery, M. D.; Wey, H. E.; Toraason, M. A.; Toxicol. Appl. Pharmacol. 1995, 130, 41.

17. Pulido, M. D.; Parrish, A. R.; Mutat. Res. 2003, 533, 227.

18. Demicheli, C.; Ochoa, R.; Lula, I. S.; Gozzo, F. C.; Eberlin, M. N.; Frézard, F.; Appl. Organomet. Chem. 2003, 17, 226.

19. Dzamitika, S. A.; Falcão, C. A. B.; Oliveira, F. B.; Marbeuf, C.; Garnier-Suillerot, A.; Demicheli, C.; Rossi-Bergmann, B.; Frézard, F.; Chem. Biol. Interact. 2006, 160, 217.

20. Flores, E. M. M.; Santos, E. P.; Barin, J. S.; Zanella, R.; Dressler, V. L.; Bittencourt, C. F.; J. Anal. At. Spectrom. 2002, 17, 819.

21. Flores, E. M. M.; Paula, F. R.; Silva, E. F. B.; Moraes, D. P.; Paniz, J. N. G.; Santos, E. P.; Dressler, V. L.; Bittencourt, C. F.; At. Spectrosc. 2003, 24, 15.

22. Cabral, L. M.; Juliano, V. N. M.; Dias, L. R. S.; Dornelas, C. B.; Rodigues, C. R.; Villardi, M.; Castro, H. C.; Santos, T. C.; Mem. Inst. Oswaldo Cruz 2008, 103, 130.

23. Ferreira, S. L. C.; dos Santos, W. N. L.; dos Santos, I. F.; Junior, M. M. S.; Silva, L. O. B.; Barbosa, U. A.; de Santana, F. A.; Queiroz, A. F. S.; Microchem. J. 2014, 114, 22.

24. Lundstedt, T.; Seifert, E.; Abramo, L.; Thelin, B.; Nyström, A.; Pettersen, J.; Bergman, R.; Chemom. Intell. Lab. Syst. 1998, $32,3$.

25. Ferreira, S. L. C.; Lemos, V. A.; de Carvalho, V. S.; da Silva, E. G. P.; Queiroz, A. F. S.; Felix, C. S. A.; da Silva, D. L. F.; Dourado, G. B.; Oliveira, R. V.; Microchem. J. 2018, 140, 176.

26. Statistica, version 10; StatSoft, Inc., USA, 2010.

27. Dédina, J.; Tsalev, D. L.; Hydride Generation Atomic Absorption Spectrometry, vol. 6, $1^{\text {st }}$ ed.; John Wiley \& Sons Ltd: Chichester, UK, 1995.

28. Instituto Nacional de Metrologia, Normalização e Qualidade Industrial (INMETRO); DOQ-CGCRE-008 Orientação sobre Validação de Métodos Analíticos, 2016. Available at http:// www.inmetro.gov.br/Sidoq/Arquivos/CGCRE/DOQ/DOQCGCRE-8_05.pdf, accessed in July 2020.

29. de Souza, S. V. C.; Junqueira, R. G.; Anal. Chim. Acta 2005, $552,25$.

30. Association of Official Analytical Chemists (AOAC); Guidelines for Standard Method Performance Requirements, 2016, available at http://www.eoma.aoac.org/app_f.pdf, accessed in July 2020.

31. Santos, V. S.; Santos, W. D. R.; Kubota, L. T.; Tarley, C. R. T.; J. Pharm. Biomed. Anal. 2009, 50, 151.

32. Lukaszczyk, L.; Zyrnicki, W.; J. Pharm. Biomed. Anal. 2010, $52,747$.

33. Seby, F.; Gleyse, C.; Grosso, O.; Plau, B.; Donard, O. F. X.; Anal. Bioanal. Chem. 2012, 404, 2939.

34. Franco, M. A.; Barbosa, A. C.; Rath, S.; Dorea, J. G.; Am. J. Trop. Med. Hyg. 1995, 52, 435. 
35. Rath, S.; Jardim, W. F.; Dorea, J. G.; Fresenius'J. Anal. Chem. 1997, 358, 548.

36. González, M. J.; Renedo, O. D.; Martinez, M. J.; Talanta 2005, $68,67$.

37. González, M. J.; Renedo, O. D.; Martinez, M. J.; Electroanalysis 2006, 18, 1159.

38. González, M. J.; Renedo, O. D.; Martinez, M. J.; Talanta 2007, 71,691 .
39. Renedo, O. D.; Martinez, M. J.; Electrochem. Commun. 2007, 9, 820 .

Submitted: March 11, 2020

Published online: July 22, 2020 